Annals of Warsaw University of Life Sciences - SGGW

Land Reclamation No 45 (2), 2013: 255-260

(Ann. Warsaw Univ. of Life Sci. - SGGW, Land Reclam. 45 (2), 2013)

\title{
Interactions of mercury in the environment
}

\author{
ILONA MAŁUSZYŃSKA ${ }^{1}$, AGNIESZKA POPENDA ${ }^{2}$, \\ MARCIN J. MAŁUSZYŃSKI ${ }^{1}$ \\ ${ }^{1}$ Department of Environmental Improvement, Warsaw University of Life Sciences - SGGW \\ ${ }^{2}$ Department of Chemistry, Technology of Water and Wastewater, Częstochowa University of Technology
}

\begin{abstract}
Interactions of mercury in the environment. Mercury is a pollutant of global concern largely due to its potential for biological transformation into harmful forms and bioaccumulation through the food chains. Mercury is not able to biodegrade in the environment and it forms many toxic inorganic and organic complexes. The strongest harmful effects of mercury concerns the central nervous system. The harmful effects of mercury is very stable, because the mercury compounds

of tolerance for different follow-up effects of prolonged exposure to low concentrations. It should also be pointed out that the interactions are dynamic and weakly understood at present. The better understanding of the role the afore-mentioned particles may be crucial in the to study the interaction between mercury and various environmental components and to find a substance that interacts with mercury to reduce its toxicity to living organisms.
\end{abstract} bind to enzymes. Getting into the brain, mercury displace zinc from brain tissue, and thus reduces the efficiency of the brain. Then excreted in the cell nuclei and destroys the genetic material. The antagonism between zinc and mercury partially modifies its toxic effects. Mercury is combined with active groups of proteins and amino acids, accumulating in the body. Selenium has similar affinity, limiting connects these groups with mercury, reducing its toxicity. Antagonists are also cadmium, mercury and zinc, but their effects are most likely related with the action of selenium. Antagonist for mercury is also iodine content in the thyroid gland which is lowered, the excessive concentration of mercury in the body. It is known that taking selenium, zinc and thiols, e.g. GSH and $\mathrm{NAC}$, are of prime importance in considering effects on human organisms as well as the level of its excretion. Due to the fact that interactions are dynamic and poorly understood at present the better understanding of their role requires the further studies. Despite that have been identified interactions between elements and mercury, limiting its toxic effects, we still do not have sufficient knowledge about how to reduce the negative effects of this element on the human body. The definition of what is an acceptable daily dose of mercury for humans also does not quarantee protection of the health, because we do not know the exact limits
Key words: mercury, interactions, environment

\section{INTRODUCTION}

Mercury is a pollutant of global concern largely due to its potential for biological transformation into harmful forms and bioaccumulation through the food chain.

Mercury occurs naturally within the environment in a variety of forms including elemental $\mathrm{Hg}$, as $\mathrm{Hg}^{2+}$ dissolved in water, cinnabar $(\mathrm{HgS})$, oxidized $(\mathrm{HgO})$, and organometallic compounds, such as methyl mercury $\left(\mathrm{CH}_{3} \mathrm{Hg}^{+}\right)$, the latter of which shows great potential for bioaccumulation, being recognized as the most toxic form to humans (Deng et al. 2011).

According to information presented by Leśniewska et al. (2009), 75-95\% of mercury in fish and seafood is in the form of methylmercury, which is the strong neurotoxin. The amounts of 
mercury found in food products other than fish and seafood are not so worrying because in the case of these products mercury does not appear in the form of methylmercury, which poses less threat for human health. Results of the research on the total mercury content in the muscular tissue of fish, available in the trade and coming from private breeding from surroundings of Łódź led by authors, indicates that fish contains from 0.092 (salmon) up to $0.359 \mathrm{mg} \cdot \mathrm{kg}^{-1}$ (tuna).

Results of blood and urine mercury determination among children and adults were presented by Prokopowicz et al. (2010). The concentration of mercury in the children's blood was $0.10-1.72 \mathrm{ng} \cdot \mathrm{cm}^{-3}$, while adults' blood contains $0.11-5.82 \mathrm{ng} \cdot \mathrm{cm}^{-3}$, respectively. The concentration of mercury in the urine of children and adults expressed in the creatinine was $0.01-11.54 \mathrm{ng} \cdot \mathrm{cm}^{-3}$. Authors are pointing out to the fact that regular consumption of fish (over 3 meals per month) in children and (over 5 meals per month) in women increased the concentration of mercury in blood, on average twice.

Mercury can penetrate into the human body through inhaled air. It is very important so that the man in the place in which he/she is working is exposed like least to the negative influence of factors harmful for his health.

Mercury especially in organic compounds is such a factor and therefore according to Regulation of the Labour and Social Policy Minister (Dz.U. 2002 nr 217, poz. 1833), the $\mathrm{Hg}$ concentration cannot be higher than $0.01 \mathrm{mg} \cdot \mathrm{m}^{-3}$. The total emission of mercury according to Environment (2012) is equal to $14.8 \mathrm{Mg}$. Taking into account kinds of human ac- tivity, the emission of mercury includes respectively: combustion in energy production and transformation industries - 8.77 Mg, non-industrial combustion plants $-1.78 \mathrm{Mg}$, combustion in industry - $3.47 \mathrm{Mg}$, and municipal waste incineration $-0.05 \mathrm{Mg}$.

\section{INTERACTIONS OF MERCURY}

\section{Selenium}

Mercury has a high affinity for thiol/ /sulfhydryl groups. Almost all proteins contain in their composition sulfhydryl groups, so that mercury and its compounds can interfere with the majority of enzymes and hormones occurring in animals and humans. One of the earliest biochemical changes preceding the physiological symptoms of mercury poisoning is a disorder of protein biosynthesis (WHO 1991, Syversen and Kaur 2012).

Selenium has similar affinity for the active groups of proteins, which limits the combining of those groups with mercury, reducing its toxicity. The ability of selenium to ameliorate mercury toxicity has been shown in laboratory studies (Berry and Ralston 2008, Pinheiro et al. 2009). Ralston and others (Ralston et al. 2008, Ralston 2009) have suggested that molar ratios greater than 1 : 1 are protective. Recent studies (Ralston and Raymond 2010) have shown that Seenriched diets not only prevent $\mathrm{MeHg}$ toxicity, but can also rapidly reverse some of its most severe symptoms. It is now understood that $\mathrm{MeHg}$ is a highly specific, irreversible inhibitor of Se-dependent enzymes (selenoenzymes). Selenoenzymes are required to prevent and reverse oxidative damage throughout the 
body, particularly in the brain and neuroendocrine tissues. Inhibition of selenoenzyme activities in these vulnerable tissues appears to be the proximal cause of the pathological effects known to accompany $\mathrm{MeHg}$ toxicity.

As an essential element, selenium undergoes some homeostatic regulation, but it is also highly toxic. Within species, mercury level tends to increase with size, accounting for the negative relationship between size and ratio (Burger and Gochfeld 2012). According to the authors, this variability may make it difficult to use the selenium: mercury molar ratio in risk assessment, risk management, and risk communication. Before ratios can be used in risk management, more information is needed on mercury: selenium interactions and mutual bioavailability, and on the relationship between molar ratios and health outcomes. Further, people who are selenium deficient may be more at risk from mercury toxicity than others (Burger and Gochfeld 2013).

Similar to mercury (mainly $\mathrm{MeHg}$ ), selenium is acquired by organisms when they consume food and water, and it is absorbed as selenite, selenate or organic $\mathrm{Se}$, respectively (Yang et al. 2008). Mutual antagonistic interaction between $\mathrm{Hg}$ and Se is not the only one. The literature also describes the interaction of an additive or even synergistic effect between $\mathrm{Hg}$ and Se (Dang and Wang 2011). Khan and Wang (2009) also suggest that an antagonistic or synergistic effect depends on the sensitivity of the organ/organism (which determines the threshold concentrations $[\mathrm{Hg}]$ toxicity, [Se]deficiency, and[Se]toxicity), and the relative concentrations of $\mathrm{Hg}$ and Se. However, dif- ferences across studies in the forms of $\mathrm{Se}$ and $\mathrm{Hg}$, and the route and duration of exposure make a difficult interpretation. While several animal studies have shown protection against inorganic $\mathrm{Hg}$ toxicity by selenite, there is no evidence showing protection against $\mathrm{MeHg}$ toxicity by the organic Se compounds, such as selenomethione or selenocysteine, that are the forms of Se commonly found in the human diet. There is no human data that support a protective role for $\mathrm{Se}$ with respect to Hg toxicity (Mergler et al. 2007).

\section{Glutathione (GSH) and N-Acetyl- -cysteine (NAC)}

Data given by Clarkson (1985) and Clarkson et al. (2002) indicate that GSH may play a role in the biliary excretion of methylmercury. It is assumed that intracellular GSH is involved in protecting cells. Bridges and Zalups (2005) found that mercuric conjugates of GSH are part of the uptake mechanism of inorganic mercury by the kidneys in rats. In other studies it came out that NAC increased brain mercury concentration in rats exposed to elemental mercury (Aposhian 2003). Other studies indicate that NAC conjugates of methylmercury and inorganic mercury as potentially transportable mercuric species taken up in vivo in proximal tubular epithelial cells (Zalups and Ahmad 2005). In experiment carried out with the use of canine Madin-Darby Canine kidney Cells (MDCK) cells transfected with the human organic anion transporter1 (hOAT1). Bridges and Zalups (2005) noticed that given the inefficiency of elimination of methylmercury via the bile, the known entero-hepatic cycling of methylmercury and the mer- 
cury uptake mechanisms of the kidneys and the brain. It can be stated that the main limiting factor of choosing NAC and GSH as antidotes to mercury toxicity is the possibility of redistribution of mercury to the afore-mentioned organs.

\section{Zinc and iodine}

According to data given by Goyer et al. (1995), zinc was found as metal presents in animal models in order to induce production of metallothionein, a metal binding protein, in the kidneys. Metallothionein as a low molecular weight metal has ability to bind protein with a high content of cystinyl residues and metals. Mercury is known to form a complex with metallothionein, and metallothionein has been shown to be neuroprotective on exposure to mercury vapour (Yoshida et al. 2005). Inorganic and elemental mercury induce metallothionein in the kidneys, however methylmercury does not directly induce metallothionein, but does so upon metabolism to inorganic mercury.

With respect to iodine, there is an increased excretion in the urine of arsenic, mercury, lead, aluminum, and other toxic metals. Iodine is selective in that it leaves the essential metals (e.g., iron) and removes the toxic ones ${ }^{1}$.

\section{CONCLUSIONS}

Though mercury has been known as a toxic substance for hundreds of years, much remains to be elucidated on the mechanisms by which mercury interacts and interferes with the body's biochemi-

\footnotetext{
${ }^{1} \mathrm{http}: / /$ www.regenerativenutrition.com/content. asp?id=572 (Accessed 23.09.2013).
}

cal processes (Rooney 2007). Due to the fact that mercury is not biodegradable, has very long residence time in the environment and accumulates in the trophic chain, which leads to significant concentrations in human body through consumption of food and contact with contaminated air and water, key activity is to reduce the level of mercury in the environment and to reduce human exposure to this harmful health element.

It is quite obvious that GSH and NAC play an important role in the distribution of mercury in the organism. Additionally zinc and selenium seem to have a significant impact on the mercury distribution and its protection against the toxicity.

It is supposed that taking selenium, zinc and thiols is of prime importance in considering effects of mercury on human organism as well as the level of its excretion and it requires the further investigations.

It should also be pointed out that the interactions are dynamic and weakly understood at present. The better understanding of the role the afore-mentioned particles may be crucial in the study of interaction between mercury and various environmental components and to find a substance that interacts with mercury to reduce its toxicity to living organisms.

\section{REFERENCES}

APOSHIAN H.V., MORGAN D.L., QUEEN H.L., MAIORINO R.M., APOSHIAN M.M., 2003: Vitamin C, glutathione, or lipoic acid did not decrease brain or kidney mercury in rats exposed to mercury vapor. Journal of Toxicology. Clinical Toxicology 41: 339-347. 
BALLATORI N., CLARKSON T.W. 1985: Biliary secretion of glutathione and of glutathione-metal complexes. Fundamental Applied Toxicology 5: 816-831.

BERRY M.J., RALSTON N.V.C. 2008: Mercury toxicity and the mitigating role of selenium. EcoHealth 5: 456-459.

BRIDGES C.C., ZALUPS R.K. 2005: Molecular and ionic mimicry and the transport of toxic metals. Toxicology and Applied Pharmacology 204: 274-308.

BURGER J., GOCHFELD M. 2012: Selenium and mercury molar ratios in saltwater fish from New Jersey: Individual and species variability complicate use in human health fish consumption advisories. Environmental Research 114: 12-23.

BURGER J., GOCHFELD M. 2013: Selenium and mercury molar ratios in commercial fish from New Jersey and Illinois: Variation within species and relevance to risk communication. Food and Chemical Toxicology 57: 235-245.

CLARKSON T.W. 2002: The three modern faces of mercury. Environmental Health Perspectives 110 (Suppl. 1): 11-23.

DANG F., WANG W.-X. 2011: Antagonistic interaction of mercury and selenium in marine fish is dependent on their chemical species. Environmental Science\&Technology 45: 3116-3122.

DENG C., ZHANG C., LI L., LI Z., LI N. 2011: Mercury contamination and its potential health effects in a lead-zinc mining area in the karst region of Guangxi, China. Applied Geochemistry 26: 154-159.

ENVIRONMENT 2012: Statistical Information and Elaboration, Regional and Environmental Surveys Department, Warsaw, 2012.

GOYER R., KLAASSEN C.D., WAALKES M.P. 1995: Metal Toxicology. Academic Press, San Diego: 35-37.

KHAN M.A.K., WANG F. 2009: Mercury-selenium compounds and their toxicological significance: toward a molecular understanding of the mercury-selenium antagonism. Environmental Toxicology and Chemistry 28 (8): 1567-1577.
LEŚNIEWSKA E., SZYNKOWSKA M.I., PARYJCZAK T. 2009: Main Sources of Mercury in Human Organisms not Exposed Professionally. Annual Set the Environment Protection Publication of Middle Pomeranian Scientific Society of The Environment Protection 11: 403-419.

MERGLER D., ANDERSON H.A., CHAN L.H.M., MAHAFFEY K.R., MURRAY M., SAKAMOTA M., STERN A.H. 2007: Methylmercury exposure and health effects in humans: a worldwide concern. Ambio 36: 3-11.

PINHEIRO M.C.N., De NASCIMENTO J.L.M., SILVEIRA L.C.L., DAROCHA J.B.T., ASCHNER M. 2009: Mercury and selenium - a review on aspects related to the health of human populations in the Amazon. Environmental Bioindicators 4: 222-245.

PROKOPOWICZ A., SZUŁA M., PAWLAS K., PAWLAS N., ZŁOTOWSKA R., SOBCZAK A. 2010: Environmental exposure to mercury in selected Polish regions; results of blond and urine determination among children and adults. In: Rtęć w środowisku: identyfikacja zagrożeń dla zdrowia człowieka. ed. L. Falkowska Wyd. Fundacji Rozwoju Uniwersytetu Gdańskiego, Gdańsk: 247-250.

RALSTON N.V.C. 2009: Introduction to 2nd issue on special topic: selenium and mercury as interactive environmental indicators. Environmental Bioindicators 4: 286-290.

RALSTON N.V.C., RAYMOND L.J. 2010: Dietary selenium's protective effects against methylmercury toxicity. Toxicology 278: 112-123.

RALSTON N.V.C., RALSTON C.R., BLACKWELL III, J.L., RAYMOND L.J. 2008: Dietary and tissue selenium in relation to methylmercury toxicity. Neurotoxicology 29, 802-811.

Regulation of the Labour and Social Policy Minister from 29 November 2002 on the highest acceptable concentrations and intensities of factors harmful to the health in the workplace (in Polish). Dz.U. 2002 nr 217, poz. 1833. 
ROONEY J.P.K. 2007: The role of thiols, dithiols, nutritional factors and interacting ligands in the toxicology of mercury. Toxicology 234: 145-156.

SYVERSEN T., KAUR P. 2012: The toxicology of mercury and its compounds. Journal of Trace Elements in Medicine and Biology 26, 215-226.

Environmental health criteria 118: Inorganic mercury 1991. International Programme on Chemical Safety. World Health Organization, Geneva.

YANG D.-Y., CHEN Y.-W., GUNN J.M., BELZILE N. 2008: Selenium and mercury in organisms: interactions and mechanisms. Environmental Reviews 16: 71-92.

YOSHIDA M., WATANABE C., HORIE K., SATOH M., SAWADA M., SHIMADAA. 2005: Neurobehavioral changes in metallothionein-null mice prenatally exposed to mercury vapor. Toxicology Letters 155: 361-368.

ZALUPS R.K., AHMAD S. 2005: Transport of $\mathrm{N}$-acetylcysteine Sconjugates of methylmercury in Madin-Darby canine kidney cells stably transfected with human isoform of organic anion transporter 1. Journal of Pharmacology and Experimental Therapeutics 314: 1158-1168.

Streszczenie: Interakcje rtęci $w$ środowisku. Rtęć jest zanieczyszczeniem stanowiącym ogólnoświatowy problem w dużej mierze ze względu na możliwości przekształcenia w szkodliwe formy, a także bioakumulację w łańcuchu pokarmowym. Rtęć w środowisku nie ulega biodegradacji i tworzy wiele toksycznych nieorganicznych $\mathrm{i}$ organicznych kompleksów. Najsilniejszy szkodliwy wpływ rtęci dotyczy ośrodkowego układu nerwowego. Szkodliwe działanie rtęci jest bardzo trwałe, ponieważ związki rtęci łączą się z enzymami.Dostając się do mózgu, rtęć wypiera z tkanki mózgowej cynk, osłabiając sprawność mózgu, a następnie przenika do jąder komórkowych i niszczy materiał genetyczny. Antagonizm pomiędzy cynkiem i rtęcią częściowo modyfikuje jej toksyczne dzia- łanie. Rtęć łączy się z aktywnymi grupami białek i aminokwasów, kumulując się w organizmie. Podobne powinowactwo wykazuje selen, ograniczając łączenie się tych grup z rtęcią, zmniejszając jej toksyczność. Antagonistami rtęci są również kadm i cynk, ale ich działanie jest najprawdopodobniej powiązane $\mathrm{z}$ działaniem selenu.Antagonistą dla rtęci jest również jod, którego zawartość w tarczycy ulega obniżeniu przy nadmiernym stężeniu rtęci w organizmie. Wiadomym jest, iż pobór selenu, cynku oraz niektórych tioli, np. GSH i NAC, również poziom ich wydalania są kluczowe w rozważaniu ich wpływu na organizmy żywe. Biorąc pod uwagę fakt, że reakcje zachodzące pomiędzy nimi są dynamiczne i słabo poznane, lepsze zrozumienie ich roli wymaga dalszych badań. Pomimo stwierdzenia występowania interakcji z pierwiastkami ograniczającymi toksyczne działanie rtęci, nadal nie mamy wystarczającej wiedzy na temat możliwości zmniejszenia negatywnych skutków działania tego pierwiastka na organizm człowieka. Określenie dopuszczalnych dziennych dawek rtęci dla człowieka, również nie gwarantuje zabezpieczenia stanu jego zdrowia, gdyż nie są znane dokładne granice tolerancji na różne następcze skutki długiego działania niskich stężeń tego pierwiastka. Należy również podkreślić, że zjawisko interakcji jest nadal słabo rozpoznane i podlega ciagłym zmianom. Lepsze zrozumienie roli wcześniej wymienionych składników może być konieczne w celu określenia oddziaływania pomiędzy rtęcią i różnymi składnikami środowiska oraz znalezienia substancji, które wchodzą $\mathrm{w}$ interakcje z rtęcią, zmniejszając jej toksyczność dla organizmów żywych.

Stowa kluczowe: rtęć, interakcje, środowisko

MS. received in December 2013
Author's address:
Ilona Małuszyńska
Katedra Kształtowania Środowiska
Wydział Budownictwa i Inżynierii Środowiska SGGW
ul. Nowoursynowska 159, 02-776 Warszawa
Poland
e-mail: ilona_maluszynska@sggw.pl 